\title{
Geochemistry of the rare earth elements in the sparkling groundwaters of the Caucasus ridge, Russia
}

\author{
Evgenia Chirkova ${ }^{1,3, *}$, Ekaterina Baranovskaya ${ }^{1}$, Natalia Kharitonova $^{1,2,3}$, Vasily \\ Lavrushin $^{3}$, Georgy Chelnokov ${ }^{2,3}$, and Ivan Bragin ${ }^{2,3}$ \\ ${ }^{1}$ Lomonosov Moscow State University, Moscow, Russia \\ ${ }^{2}$ Geological Institute, Russian Academy of Sciences, Moscow, Russia \\ ${ }^{3}$ Far East Geological Institute, Far East Branch, Russian Academy of Sciences, Vladivostok, Russia
}

\begin{abstract}
The paper presents data on the content and distribution of rare earth elements (REE) in the high $\mathrm{pCO}_{2}$ mineral waters of the Caucasus mountain-folded region. It is shown that the concentrations of $\mathrm{REE}_{\text {total }}$ are rather high in the studied waters. However, they vary in a very wide range (from 0.46 to $50.37 \mu \mathrm{g} / \mathrm{L}$ ). A characteristic feature of these waters is the predominance of light REE in comparison with heavy REE in them. The distinct correlation of $\mathrm{REE}_{\text {total }}$ in the solution from the concentration of iron and aluminum in it indicates that the absolute contents of REE in the mineral waters of the region are regulated not only by $\mathrm{pH}$ and Eh of the solution but also by the content of these elements in it.
\end{abstract}

\section{Introduction}

One of the most important tasks of hydrogeology is to reconstruct the physical and chemical conditions of the groundwater formation and understand the mechanisms of subsequent groundwater transformation. A number of methods are actively used for these purposes, such as genetic coefficients, isotopic ratios and, recently, rare earth elements (REE). Despite the fact that a significant number of works $[1,2]$ are devoted to the study of mineral waters of the Caucasus region, the group of REE in them is practically not investigated. In this regard, the main purpose of this work was to get new data on the REEs distribution and fractionation in the mineral springs and wells located within of the Greater Caucasus. Additionally, we try to specify the main REE species in these aqueous solutions.

\section{Objects and research methods}

The work was based on the results of sampling of 20 sources of the $\mathrm{CO}_{2}$-rich sparkling mineral waters of the Caucasus mountain system during two periods (1998-2003 years and 2016 field season). Sampling sites are presented in Figure 1.

\footnotetext{
* Corresponding author: Idiotjimmy95@gmail.com
} 


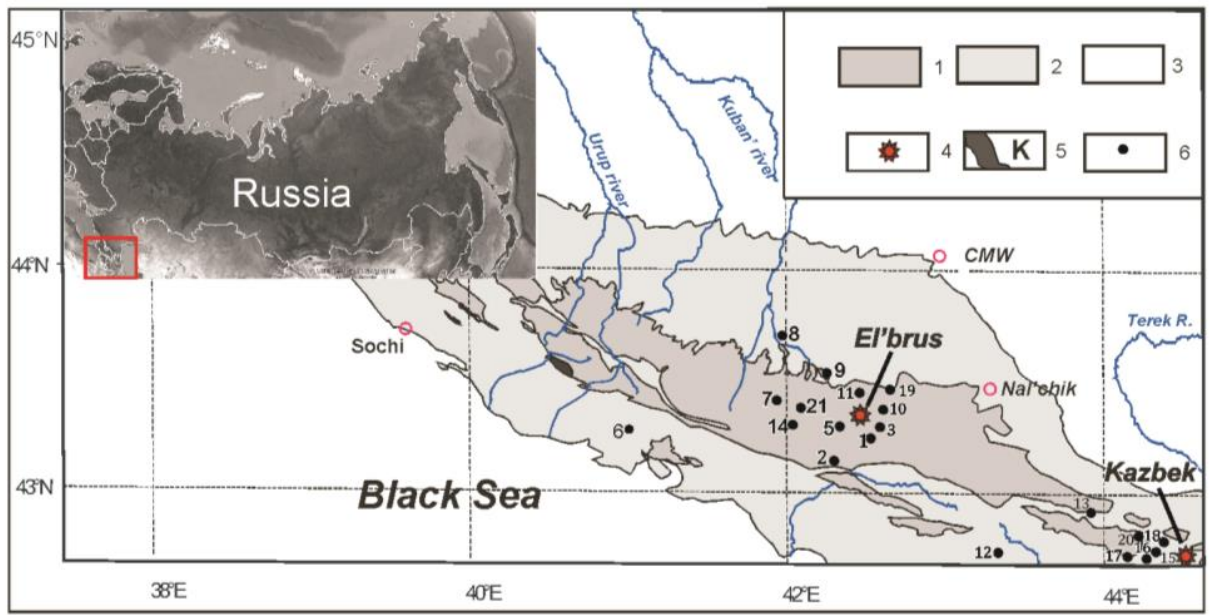

Fig. 1. Location of the studied object and sampling points: 1- Proterozoic-Paleozoic basement; 2Mesozoic sedimentary rocks; 3 - Cainozoic sediments; 4 - volcanoes; 5 -igneous rocks; 6 - sampling points.

Unstable parameters ( $\mathrm{t}, \mathrm{pH}, \mathrm{Eh}, \mathrm{EC})$ were measured directly at the sampling site. The water samples selected for laboratory determination of basic cations and microelements were filtered through $0,45 \mu \mathrm{m}$ filters in bottles of $250 \mathrm{ml}$ and acidified with ultrapure $\mathrm{HNO}_{3}$ directly during sampling. The water samples selected for the determination of the main anions were filtered, but they were not oxidized, and directly transported for further research in the refrigeration chamber at a temperature of $5-7^{\circ} \mathrm{C}$.

Laboratory tests were performed using a wide range of analytical methods. The content of $\mathrm{Cl}^{-}$and $\mathrm{HCO}_{3}^{-}$was determined using titrimetric analysis method; $\mathrm{F}^{-}$- using the ionselective measurements method; $\mathrm{Li}, \mathrm{B}, \mathrm{Na}, \mathrm{Mg}, \mathrm{Al}, \mathrm{Si}, \mathrm{P}, \mathrm{S}, \mathrm{K}, \mathrm{Ca}, \mathrm{Ti}, \mathrm{V}, \mathrm{Cr}, \mathrm{Mn}, \mathrm{Fe}, \mathrm{Co}$, $\mathrm{Ni}, \mathrm{Cu}, \mathrm{Zn}, \mathrm{Sr}, \mathrm{Ba}$ were analyzed by ICP-AES (iCAP-6500, Thermo Scientific, USA); REE and micro components were determined by ICP-MS (X-7, Thermo Elemental, USA). The elements determination accuracy was higher than $7 \%$ RSD.

\section{Research results}

The major elements composition of the studied samples is shown in Figure 2. Data interpretation indicates that these mineral waters are hydrocarbonate-chloride or almost completely hydrocarbonate by the anionic composition. The cationic contents of the water is varied, however, the prevailing element is calcium.

It stands to mention that the concentrations of REE in the carbonated mineral waters of these sources vary in a significantly wide range, from 0.46 to $50.37 \mu \mathrm{g} / \mathrm{L}$ (table 1 ). The lowest contents of REE are typical for mineral waters of the springs «Britta» of $0,81 \mu \mathrm{g} / \mathrm{L}$ and the maximum concentrations of REE were found in the springs of Matsota $50,37 \mu \mathrm{g} / \mathrm{L}$.

A characteristic feature of the studied waters is the predominance of light REE (LREE) in them in comparison with heavy REE (HREE). The exceptions are present in the following three springs: Uchkulanichi, Garakol and Matsota. In other cases, the amount of LREE is approximately 60,3 - 82,5\% of all REE in solution. 

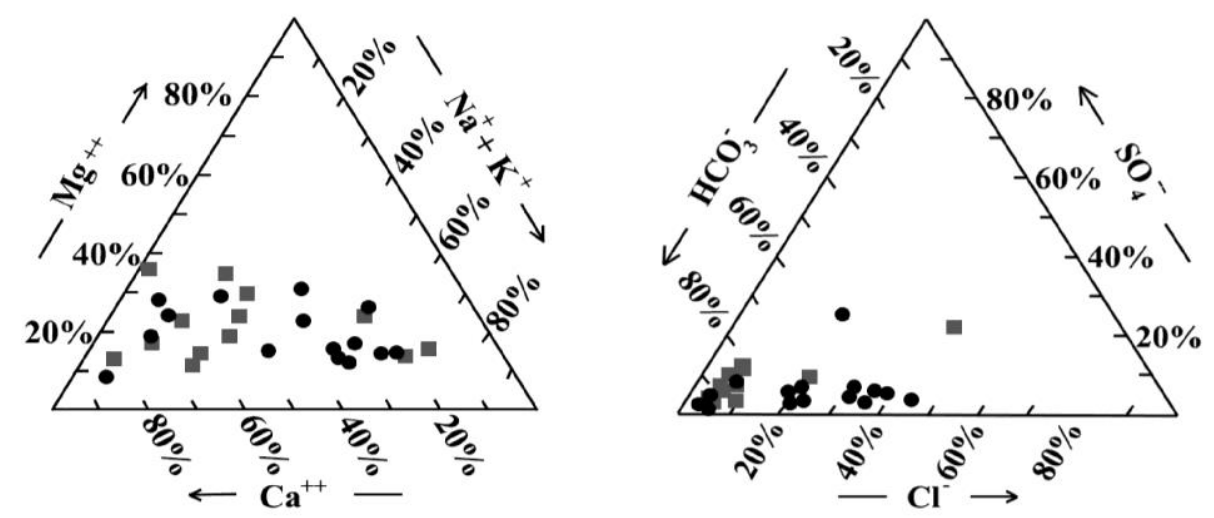

Fig. 2. Major elements composition of the investigated waters: squares - samples 1-3 and 5-10; circles-samples 4 and 11-21. The sample numbers correspond to the numbers in the table 1 .

The predominance of LREE over HREE is generally fixed in $\mathrm{HCO}_{3}-\mathrm{SO}_{4}-\mathrm{Cl}$ waters as well as in $\mathrm{HCO}_{3}$. No distinct pattern was revealed in the $\mathrm{HCO}_{3}{ }^{-} \mathrm{Cl}$ waters in the ratio of LREE and HREE: there is a predominance of LREE in some springs, in others - a sharp prevail of HREE. Comparison of the REE content and $\mathrm{pH}$ of aqueous solutions confirmed the known inverse dependence of the REE concentration in the solution on the value of $\mathrm{pH}$. Since the studied waters within the Caucasus region are slightly alkaline solutions ( $\mathrm{pH} 5,5-$ 7,2 ), the REE concentrations in them are average and they are typical for similar waters [3].

Comparison of the content of REE in the solution related to the presence of aluminum, iron and manganese in it was carried out. The resulting diagrams clearly demonstrate that the ratio $\mathrm{REE}_{\text {total }}-\mathrm{Fe}_{\text {total }}$ and $\mathrm{REE} \mathrm{E}_{\text {total }} \mathrm{Al}$ (fig.3) show a distinct correlation, while between $\mathrm{REE}_{\text {total }}$ and $\mathrm{Mn}_{\text {total }}$ such a connection could not be found. Such dependences prove that it is iron and aluminum that control the absolute content of REE in waters since there are very strong processes of co-deposition of dissolved REE on the colloid's surface of oxides and hydroxides $\mathrm{Fe}, \mathrm{Al}$ and $\mathrm{Mn}$.
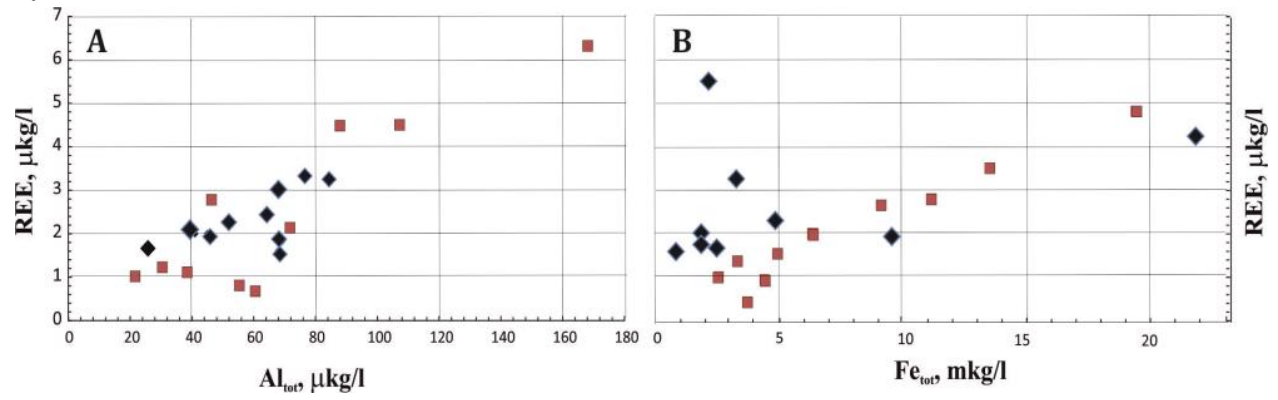

Fig. 3 . Dependence of REE concentration on aluminum (A) and iron (B) contents. Black rhombuses 4 and 11-21 samples, red squares 1-3 and 5-10 samples. The sample numbers correspond to the numbers in the table 1.

NASC-normalized profiles of REE distribution in the studied waters are characterized by a rise of the curve in the areas of heavy REE, which is typical for $\mathrm{CO}_{2}$-rich springs of the Far East of Russia [3, 4].

Anomalies of some elements (cerium, europium, thulium) were calculated to determine the nature of the distribution of individual REE in relation to neighboring elements. Completed calculations showed a distinct negative anomaly of cerium for almost all 
inverstigated springs, excluding Chemartkol and Matsota springs. Comparison of anomalies of europium and cerium did not reveal any dependencies. Several springs (table 1) indicate obviously positive europium anomaly. Two springs (Chemartkol and Matsota) discovered a distinct negative anomaly of thulium.

It is known that cerium and europium differ from other REE as they are sensitive to redox potential and $\mathrm{pH}$. The manifestation of the anomaly-Ce is clearly regulated by Eh of the studied waters, while the anomaly-Eu does not follow this trend.

Table 1. The REE content (in $\mu \mathrm{g} / \mathrm{L}$ ) in the mineral waters of the Greater Caucasus ridge.

\begin{tabular}{|l|l|c|c|c|c|c|c|c|}
\hline Samples & \multicolumn{1}{|c|}{$\begin{array}{c}\text { Sampling } \\
\text { place }\end{array}$} & $\mathrm{pH}$ & LREE & MREE & HREE & REE $_{\text {tot }}$ & Ce/Ce* & Eu/Eu* \\
\hline $1^{*}$ & Terskol & 6.12 & 2.06 & 0.82 & 1.79 & 4.7 & 0.76 & 1.84 \\
\hline $2^{*}$ & Jantugan & 6.54 & 1.75 & 0.33 & 1.01 & 3.1 & 0.68 & 0.58 \\
\hline $3^{*}$ & \multirow{2}{*}{ Irik-narzan } & \multirow{2}{*}{6.88} & 0.51 & 0.14 & 0.33 & 1.0 & 0.97 & 0.69 \\
\cline { 1 - 8 } $4^{* *}$ & & 1.11 & 0.41 & 0.50 & 2.0 & 0.72 & 0.71 \\
\hline $5^{*}$ & Adyl-su & 6.88 & 1.50 & 0.29 & 1.06 & 2.9 & 0.73 & 1.03 \\
\hline $6^{*}$ & Dombai (well) & 6.87 & 0.29 & 0.07 & 0.27 & 0.6 & - & - \\
\hline $7^{*}$ & Goraly-kol & 6.69 & 0.67 & 0.18 & 1.19 & 2.0 & 0.73 & 0.74 \\
\hline $8^{*}$ & Kert-Meli & 6.66 & 2.31 & 0.76 & 1.81 & 4.9 & 0.65 & 0.75 \\
\hline $9^{*}$ & Karzhurt & 6.80 & 0.31 & 0.04 & 0.11 & 0.5 & 0.31 & 1.28 \\
\hline $10^{*}$ & Shaukol & 6.50 & 2.68 & 0.77 & 2.63 & 6.1 & 0.74 & 1.07 \\
\hline $11^{*}$ & Ullu-Kam & 5.75 & 0.55 & 0.16 & 0.42 & 1.1 & 0.43 & 4.53 \\
\hline $12^{*}$ & Laboda & 5.40 & 0.40 & 0.06 & 0.23 & 0.7 & 0.98 & 0.74 \\
\hline $13^{*}$ & Matsota & 5.35 & 0.85 & 0.39 & 2.47 & 3.7 & 1.08 & 0.53 \\
\hline $14^{*}$ & Mahar & 5.14 & 0.94 & 0.04 & 0.06 & 1.0 & 0.48 & - \\
\hline $15 *$ & Erman lower & 5.91 & 2.68 & 0.77 & 2.63 & 6.1 & 0.37 & 4.53 \\
\hline $16^{*}$ & Edissa & 6.03 & 0.55 & 0.16 & 0.42 & 1.1 & 0.50 & 4.53 \\
\hline $17 * *$ & Zgubir-lower & 6.10 & 8.13 & 2.87 & 3.97 & 15.0 & 0.71 & 2.98 \\
\hline $18^{* *}$ & Britata & 6.07 & 0.86 & 0.24 & 0.49 & 1.6 & 0.35 & - \\
\hline $19 * *$ & Chemartkol & 6.89 & 6.85 & 1.36 & 2.88 & 11.1 & 1.06 & 1.29 \\
\hline $20^{* *}$ & Suna & 6.24 & 38.95 & 5.52 & 5.90 & 50.4 & 0.29 & 4.53 \\
\hline $21^{* *}$ & Uchkulanichi & 6.36 & 1.55 & 0.52 & 2.39 & 4.5 & 0.64 & 0.47 \\
\hline & & & & & & & & \\
\hline
\end{tabular}

* - samples taken during the 2016 field season, ** - samples taken during 1998-2003 years

One of the important mechanisms that help to solve the issue of the mobility of REE in aqueous solutions is the calculation of their migration forms. The authors of this paper carried out a calculation of the forms of REE migration for three springs - Mahar, Matsota and Laboda. These springs were selected for the calculation in order to understand how the composition of REE ligands in the solution changes depending on the ionic composition of mineral waters.

In this work, the software package Selector-Windows was used to calculate inorganic forms of REE species, which used a database of thermodynamic data SUPCRT 2007 containing thermodynamic parameters for all REE. The following components were used in the calculations: $\mathrm{REE}^{3+}, \mathrm{REE}\left[\mathrm{CO}_{3}\right]^{+}, \mathrm{REE}\left[\mathrm{HCO}_{3}\right]^{2+}, \mathrm{REE}\left[\mathrm{OH}_{2}\right]^{+}, \mathrm{REE}[\mathrm{Cl}]^{2+}, \mathrm{REE}[\mathrm{F}]^{2+}$, $\mathrm{REE}\left[\mathrm{SO}_{4}\right]^{+}, \mathrm{REE}[\mathrm{O}]^{+}, \mathrm{REE}\left[\mathrm{O}_{2}\right]^{-}, \mathrm{REE}\left[\mathrm{O}_{2} \mathrm{H}\right]^{*}, \mathrm{Ce}^{4+}$, and $\mathrm{Eu}^{2+}$. 
The results of calculations show that the main REE species in all simulated springs are carbonate complexes $\left(\mathrm{REE}\left[\mathrm{CO}_{3}\right]^{+}\right.$and $\left.\mathrm{REE}\left[\mathrm{HCO}_{3}\right]^{2+}\right)$, the second most common specie is $\mathrm{REE}^{3+}$. Sulfate and chloride complexes are practically absent in these waters. A regularity was established in the increase of carbonate complexes when moving from LREE towards HREE. The number of the uncomplexed form decreases in the direction of heavier REE. A small amount of $\mathrm{REE}[\mathrm{Cl}]^{2+}$ was found in the Mahar spring, due to the chemical type of this water.

\section{Conclusion}

The conducted research allowed to identify the main features of the distribution and water migration of REE in the carbonated mineral waters of the Caucasus. It was found that the concentrations of $\mathrm{REE}_{\text {total }}$ in the carbonated mineral waters of the springs of Elbrus region vary significantly, from 0.46 to $50.37 \mu \mathrm{g} / \mathrm{l}$. A characteristic feature of the studied hydrocarbon waters is the predominance of light REE in them in comparison with heavy REE. The distinct correlation of the total number of REE in the solution related to the concentration of iron and aluminum in it indicates that these particular elements control the absolute contents of REE in the waters. The content of REE is subject to $\mathrm{pH}$ value, which confirmed the previously established inverse dependence of REE concentration in the solution on $\mathrm{pH}$ value. The main REE species in all simulated springs is carbonate complexes $\left(\mathrm{REE}\left[\mathrm{CO}_{3}\right]^{+}\right.$и $\left.\mathrm{REE}\left[\mathrm{HCO}_{3}\right]^{2+}\right)$, the second most common complex is the form of $\mathrm{REE}^{3+}$. A regularity was established in the increase of carbonate complexes when moving from LREE towards HREE. The number of the uncomplexed form decreases in the direction of heavier REE.

Acknowledgements.This work was supported by the grant of the Russian Science Foundation № 1817-00245.

\section{References}

1. V.Y. Lavrushin, Underground fluids of the Greater Caucasus and its framing. M., (2012)

2. S.R.Krainov, Ya.G.Petrova, I.V. Baturinskaia, Geochem., 3, 315-326 (1973)

3. N.A. Kharitonova, E.A. Vakh, G.A. Chelnokov, O.V. Chudaev, I.A. Aleksandrov, I.V. Bragin, Russ. Jour. of Pacific Geol., 10, 2 (2016)

4. N.A.Kharitonova, G.A.Chelnokov, O.V.Chudaev, I.V.Bragin, I.A.Alexandrov, Procedia Earth and Planetary Science, 17, 412-415 (2017) 